\title{
Peer Tutoring Instructional Strategy and Senior Secondary School Computer Studies Students' Academic Achievement in Enugu State, Nigeria
}

\author{
Osondu*, Stella Ifeoma
}

Department of Science Education, Michael Okpara University of Agriculture, Umudike Abia State

DOI: $10.36347 /$ sjet.2021.v09i02.003

| Received: 21.01.2021 | Accepted: 04.02.2021 | Published: 28.02.2021

*Corresponding author: Osondu

Abstract

Original Research Article

This study investigated the effect of peer tutoring instructional strategy and senior Secondary school Computer Studies students' academic achievement in Enugu State, Nigeria. The study employed a non equivalent control group quasi experimental design. The sample for the study comprised of seventy eight (78) Senior Secondary School II (SS II) students drawn from two co-education schools in Enugu East Local Government Area of Enugu State, Nigeria. Two research questions and two null hypotheses tested at 0.05 level of significance guided the study. Computer Studies Achievement Test (CSAT) with a reliability coefficient of 0.75 using KR-20 was adopted for this study. The instrument was duly validated. Mean, Standard Deviation and ANCOVA statistic was used to answer the research questions and test the research hypotheses respectively. The results revealed that students taught Computer Studies using reciprocal peer tutoring instructional strategy recorded higher achievement than those taught using conventional method (lecture method). Female students taught Computer Studies using reciprocal peer instructional strategy obtained slightly higher mean score than male students. Again, there is a significant difference in Computer Studies academic achievement between students who are taught using reciprocal peer tutoring instructional strategy and those taught using conventional method (lecture method). And, there is no significant difference in Computer Studies academic achievement between male and female students taught using reciprocal peer tutoring instructional strategy. The recommendations among others are:- There should be training and retraining of teachers through seminar and workshops organized by schools, non-government organization and ministries of education to aid the teacher's acquire and adopt students centered approach in teaching to improve the student's academic achievement in Computer Studies. Management of institutions should organize and sponsor seminars, conference and workshops in every secondary school during the long vacation to educate the teacher's on the new findings to better the students' academic achievement in their areas. Government at all level should in providing special grant to enable teachers undergo professional training courses in their area of specialization.

Keywords: Computer Studies Enugu State Achievement Tutoring Instructional.

Copyright $\left({ }_{0} 2021\right.$ The Author(s): This is an open-access article distributed under the terms of the Creative Commons Attribution 4.0 International License (CC BY-NC 4.0) which permits unrestricted use, distribution, and reproduction in any medium for non-commercial use provided the original author and source are credited.

\section{INTRODUCTION}

Nigeria education is guided by the National Policy on Education which provides for formal as well as non-formal modes of delivery [1]. The guiding principles of education in Nigeria is to equip every citizen with such knowledge, skills , attitudes and value that will enable him derive maximum benefits from the membership of his society, to live a fulfilling life and contribute towards the development and welfare of the community [1]. Therefore, education is seen as bedrock of the society which is fostered through teaching. To attain to these goals, teachers needs to adopt certain techniques and teaching approaches in science and science related courses . Such approaches include: Lecture method, demonstration, peer tutoring, laboratory method, and field trip, discussion etc. All these are in attempt to enhance students' academic achievement in subject.

Ebenebe [2] poor academic achievement has been a major problem in Nigeria public secondary school examination. Poor academic achievement of students (male and female) in a particular subject like Computer Studies in secondary schools has been associated with two factors: quality and quantity of teacher and quality of teaching facilities and methods [3]. Cantrell [4] also noted that poor academic achievement may be attributed to poor and conventional method of teaching which has failed to impact the necessary knowledge and skills comprehensively to the students' academic achievement. If the goals and 
objectives of Computer Studies must be realized at the secondary school level, there should be fundamental changes in the teaching/learning process. This change would also involve a new paradigm shift and focus on effective utilization of instructional strategy. This is because today's workplace compared with modernization, technological advancement in the society demands individuals (male and female) with creative thinking skills, problems solving skills which the conventional models of teaching (subject matter absorption) does little to teach students [2]. Poor performance at school or at work indicates a problem, which could be solved by instructional intervention only or through a combination of instructional strategies.

Various teaching methods are used by teachers in the teaching of Computer Studies aimed at bringing about meaningful learning. These include lecture method, demonstration method, discovery, project, discussion, inquiry among many others. The most commonly used is the lecture method. Lecture method is the teacher-centered method, which is seen as the traditional talk-chalk method of teaching. Here the teacher does the talking while students serve as receiver only by listening and taking down notes. Obeka [5] described lecture method as a teacher-centered method. He further stressed that the method enhances acquisition of subject matter pre-dominantly under the memorization and close supervision of the students by the teacher. Lecture method is one of science teaching instructions that encourage rote learning and regurgitation of information without necessarily facilitating understanding, and this does not enhance academic achievement in science $[6,7]$.

Lecture method is employed by most science teachers because of some of its advantages which include the fact that it can be used to cover a large content area at a time and the students are given the same content at the same time. Another major advantage is that it can be used to teach a large class which is a prominent feature in most Nigeria secondary schools. Lecture method can be very useful in teaching when used in conjunction with other methods especially for the purpose of introducing the topic. Despite all these advantages, the lecture method employed in the teaching of Computer Studies and other sciences has some flaws, which might be one of the causes of the poor achievement in the sciences. According to Awotua-Efebo [8], the lecture method is mainly teacher - centered, with the students being consistently passive and contents are taught as absolute knowledge. This method had failed in the recognition of the uniqueness of the inquiry-based nature of science, collaborative and cooperativeness of human nature.

Furthermore, lecture method does not facilitate the development of reasoning skills and processes in the students. These, among other reasons had not enhanced learning in students and thus had led to poor achievement of students in the Computer Studies. It has been observed that effective teaching may facilitate learning and make it more meaningful. In line with this, Sander [9] stated that effective teaching helps the learner to learn better, while poor teaching would naturally lead to poor learning and consequently poor achievement. The basic factors responsible for students ${ }^{\text {ee }}$ under-achievement in science can be grouped into teacher related and facility-oriented factors. These factors include the materials used, and the teaching method employed, among other things. Unfortunately, evidence from literature showed that most science teachers in Nigeria secondary schools predominately use lecture method in teaching due to poor knowledge and none exposure to other learner centered method leading to poor achievement and retention [10, 11]. Hence, the need to try out peer tutoring instructional strategy.

Peer tutoring is a flexible, peer-mediated strategy that involves students serving as academic tutors and tutees. It is where higher performing student is paired with a lower performing student to review critical academic or behavioral concepts. Moreneo and Duran [12] describe peer tutoring as a method of cooperative learning based on the creation of pairs of students with a lopsided relationship; that is, the tutor and tutee do not have equal academic ability but they share a common goal. This goal must be achieved through a relationship framework organized by the teacher. Peer tutoring is an instructional strategy of students' partnership, linking high achieving students with lower achieving students for structured reading, discussion and information exchange among students, during lesson Rohrbeck, Ginsburg block, Fontuzzo and Miller [13]. Paul, Lisa and Vanesa [14] defined peer tutoring as an instructional strategy that partners students to help one another learn material, reinforce skills or practice a learned task. Peer tutoring is regarded as an excellent resource for facilitating the mastery of interpersonal competencies. Fuchs, Fuchs, Mathes, and Martinez [15] assert that socialization experiences that occur during peer tutoring can benefit both the tutor and the tutee by encouraging students to learn and increase their social standing among peers. Peer tutoring was found to be helpful in socialization experience as the level of interaction among students both inside and outside the classroom improved significantly. Whitman [16] and Annis [17] who stated that peer tutoring can helped students perform better on higher order conceptual understanding scales than students who read the material simply for study purposes. Oviawe [18] also asserts that peer tutoring serves as an effective way to improve self-esteem in students. Peer tutoring aids interaction among peers not only academically but also socially.

Peer tutoring can be incidental or structured. Incidental peer tutoring often takes place, either at 
school or while students are playing after school or when they are socializing. It occurs whenever children are cooperating, playing or studying and one guides the others. On the other hand, structured peer tutoring refers to the type implemented in specific cases and for specific subjects, following a well-structured plan prepared by the teacher. Structured peer tutoring is spontaneously used by experienced teachers who are able to plan well in advance and are familiar on how to combine tutors and tutees appropriately in order to have good results. Structured peer tutoring can be in so many forms such as Class wide Peer Tutoring (CWPT), Cross-age Peer Tutoring (CAPT), Peer Assisted Learning Strategies (PALS), Same-age Peer Tutoring (SAPT) and Reciprocal Peer Tutoring (RPT). The Reciprocal Peer Tutoring (RPT) adopted in this study involves dividing the class into group of two to five. Two or more students alternate between acting as the tutor and tutee during each session, with equitable time in each role. Often, higher performing students are paired with lower performing students. RPT utilizes a structured format that encourages teaching material, monitoring answers, and evaluating and encouraging peers. Both group and individual rewards may be earned to motivate and maximize learning. Students in RPT may prepare the instructional materials and are responsible for monitoring and evaluating their peers once they have selected a goal and reward as outlined by their teacher.

One of the problems that attract public concern in Nigeria today is the gender gap in academic performance of students in schools. This observable disparity has been blamed on a number of factors, including social, economic, and cultural stereotyping. Gender means the socially/culturally constructed characteristics and roles which are associated to males and females in any society [19]. Gender is the outcome of cultural learning and socialization which continues throughout life because undue attention is paid to socialization during childhood. It is socially constructed and not biologically determined. Gender ascribes some unique characters to males and others to females. Several studies, Oyenuga [20], Jimoh [21], Nzewi [22]; [19] have shown differential performance in Vocational Education / trade subjects, science and science related subjects in secondary schools as a result of gender, while some other studies such as Ogundola and Fakorede [23]; Owodunni and Ogundola [24, 30] who found no gender influences in vocational education trade subjects, science and science related subject achievement at the secondary school level. The need to inculcate in students' the workplace basic and thinking skills that will enable them to fit properly in the world of work and improve their performance, encourage both male and female students' participation called for effective instructional strategies.

\section{Purpose of the Study}

The main purpose of the study is to investigate the effects of peer tutoring instructional strategy (reciprocal peer tutoring instructional strategy) on academic achievement of senior secondary school students in Computer Studies in Enugu East Local government of Enugu State. Specifically, the study sought to:

1. Determine the difference in Computer Studies academic achievement between students taught using reciprocal peer tutoring instructional strategy and those taught using conventional method

2. Determine the difference in Computer Studies academic achievement between male and female students taught using reciprocal peer tutoring instructional strategy

\section{Research questions}

The following research questions guided the study

1. What is the mean difference in Computer Studies academic achievement between students taught using reciprocal peer tutoring instructional strategy and those taught using conventional method?

2. What is the mean difference in Computer Studies academic achievement between male and female students taught using reciprocal peer tutoring instructional strategy?

\section{Research Hypothesis}

Two null hypotheses guided the study and were tested at 0.05 level of significance:

1. There is no significant difference in Computer Studies academic achievement between students who are taught using reciprocal peer tutoring instructional strategy and those taught using conventional methods (lecture method).

2. There is no significant difference in Computer Studies academic achievement between male and female students taught using reciprocal peer tutoring instructional strategy.

\section{METHOD}

The study was non equivalent control group quasiexperimental research design consisting of treatment and control groups respectively. The design was considered appropriate for the study because intact classes were used instead of randomly composed samples. Simple random sampling technique was used to select 78 respondents from 31 secondary schools in Enugu East LGA. Only two co-educational secondary schools were randomly sampled due to the experimental nature of the study. One of the schools was assigned to experimental/treatment $(n=40)$ group and the other one was assigned to control $(n=38)$ group. In each of the schools sampled, a stream of SS II was randomly sampled for experimental treatment and control respectively.

The instrument used for data collected was Computer Studies Achievement Test (CSAT) constructed by the researcher based on the Computer Studies topics; logic circuit, computer files and handling of computer files taught was part of SS II 
Computer Studies curriculum. The instrument was subjected to face validation by two lecturers in Computer and Robotics Education of the University of Nigeria, Nsukka. The reliability of the instrument was established using Kuder- Richardson 20 method, which yielded 0.75 as its reliability coefficient. The data collected with the instrument were analyzes using mean statistic and research hypotheses tested using ANCOVA statistic.

Two regular Computer Studies teachers of selected schools for the study were coordinated to assist in the study. This was done for one week before the commencement of the study. The co-ordination exercise was based on: the purpose of the study, the content area to be taught, the use of the lesson notes, and the general conduct of the study. For the two regular Computer Studies teachers coordinated, one taught the treatment group using reciprocal peer tutoring instructional approach while the second teacher taught the control group using the conventional (lecture) teaching method. The teachers were advised to observe the normal classroom procedures such as entry behavior, set induction, instructional procedure, and so on. The teachers were also advised to use the same length of time (four weeks) to teach the content to the groups.

In the experimental procedure, the control group, after a pre-test at the beginning, then there were 8 contacts of logic circuit, computer files and handling of computer files teaching. The control group was taught using lecture method with the presentation of instructional materials intermittently. Students were encouraged and helped to refer to their background knowledge. The students were also encouraged to memorize the major points. Then after the contacts, they received a post-test. The experimental group also received a pre-test, and then they started learning logic circuit, computer files and handling of computer files for 8 contacts. To build trust and relationship among students, they were allowed to work frequently in partnerships and small groups of 3 - 5, there was heterogeneous grouping structure based on gender, ability, language, and so on. The teacher creates learning tasks that are complex with multiple parts that allow each group member to have a part that contributes to the overall activity goal. The teacher acted as a guide, mediator, and knowledgeable consultant, as well as instructor. She gives directions, summarizes responses, and provides assistance through the use of questioning and feedback. Upon completion of instruction, posttests were conducted to determine the difference between the groups. The conditions under which the instrument was administered were kept as similar as possible in order to control for interaction between selection and instrument

\section{RESULT}

Research Question 1: What is the mean difference in Computer Studies academic achievement between students taught using reciprocal peer tutoring instructional strategy and those taught using conventional method?

Table-1: Mean and standard deviation for the experimental and control group

\begin{tabular}{|l|l|c|r|c|r|l|}
\hline Group & N & \multicolumn{2}{|l|}{ Pre-Test } & \multicolumn{2}{l|}{ Post-Test } & Mean Achievement Gain \\
\hline & & $\bar{x}$ & SD & $\bar{x}$ & SD & \\
\hline Experimental & 40 & 20.725 & 1.948 & 41.975 & 2.259 & 21.250 \\
Control & 38 & 19.921 & 2.058 & 29.500 & 2.920 & 9.579 \\
\hline
\end{tabular}

The result presented in table 1 shows that the experimental pretest and post test mean scores are 20.725 and 41.975 with standard deviation scores of 1.948 and 2.259 respectively. Also, the control group has pretest and post test mean scores as 19.921 and 29.500 with standard deviation scores of 2.058 and 2.920 respectively. The mean achievement gain for the treatment group was 21.250 while the mean gain in the control group was 9.579

From this analysis, it showed that learning took place. This is because the two groups achieved higher mean score in their posttest than their pretest. However, the posttest mean achievement score of the experimental group was higher than the control group. This further means that students taught Computer Studies using reciprocal peer tutoring instructional strategy recorded higher achievement than those taught using conventional method (lecture method).

\footnotetext{
Research Question 2: What is the mean difference in Computer Studies academic achievement between male and female students taught using reciprocal peer tutoring instructional strategy?
}

Table-2: Mean and standard deviation for the experimental and control group across the sex

\begin{tabular}{|l|l|l|l|l|l|l|l|}
\hline Pretest & \multicolumn{9}{|c|}{ Post test } & Mean Achievement gain \\
\hline Groups & Sex & $\mathrm{N}$ & $\bar{x}$ & SD & $\bar{x}$ & SD & \\
\hline \multirow{3}{*}{ Experimental } & Male & 18 & 20.611 & 1.685 & 41.833 & 4.229 & 21.222 \\
\cline { 2 - 9 } & Female & 22 & 20.818 & 2.174 & 42.091 & 2.328 & 21.273 \\
\hline \multirow{3}{*}{ Control } & Male & 14 & 20.071 & 2.056 & 29.286 & 4.065 & 9.215 \\
\cline { 2 - 8 } & Female & 24 & 19.833 & 2.099 & 29.625 & 2.081 & 9.792 \\
\hline
\end{tabular}


Result presented in Table 2 indicates that the pretest mean score and standard deviation score for the experimental male and female are 20.611 and 1.685; 20.818 and 2.174 respectively. Similarly, the post test mean scores and standard deviation scores for the experimental male and female groups are 41.833 and $4.229 ; 42.091$ and 2.328 respectively. Also, the pretest mean scores and standard deviation scores for the control male and female are 20.071 and 2.056; 19.833 and 2.099 respectively. Also, the post test mean score and standard deviation scores for the control male and female are 29.286 and 4.065; 29.625 and 2.081 respectively. The mean achievement gain for male and female in the treatment group are 21.222 and 21.273 respectively. In the control group the gains are 9.215 and 9.792 respectively for male and female. However, there were no tangible differences in their performances. Though, results indicate that female students recorded higher achievement than their male counterparts in both the experimental and control groups.

\section{HYPOTHESES}

$\mathrm{Ho}_{1=:}$ There is no significant difference in Computer Studies academic achievement between students who are taught using reciprocal peer tutoring instructional strategy and those taught using conventional methods (lecture method).

Table-3: ANCOVA Analysis of Students' Mean Achievement Scores in Experimental and Control Groups

\begin{tabular}{|l|l|l|l|l|l|l|}
\hline Source & Type III Sum of Squares & df & Mean Square & F & Sig. & Decision \\
\hline Corrected Model & $3042.712^{\mathrm{a}}$ & 2 & 1521.356 & 226.183 & .000 & Significant \\
\hline Intercept & 750.996 & 1 & 750.996 & 111.652 & .000 & \\
\hline Pretest & 10.008 & 1 & 10.008 & 1.488 & .226 & \\
\hline Group & 2844.707 & 1 & 2844.707 & 422.928 & .000 & \\
\hline Error & 504.467 & 75 & 6.726 & & & \\
\hline Total & 104060.000 & 78 & & & & \\
\hline Corrected Total & 3547.179 & 77 & & & & \\
\hline
\end{tabular}

In table 3, group (experimental and control) as main effect, gave an f-value of 422.928 and this is significant at 0.000 . Since 0.000 is less than .05 , this means that at 0.05 level of significant, the f-value of 422.928 is significant. Therefore, $\mathrm{H}_{\mathrm{O} 1}$ was not upheld as stated, indicating that there is a significant difference in Computer Studies academic achievement between students who are taught using reciprocal peer tutoring instructional strategy and those taught using conventional method (lecture method).

$\mathrm{Ho}_{2=}$ There is no significant difference in Computer Studies academic achievement between male and female students taught using reciprocal peer tutoring instructional strategy.

Table-4: ANCOVA Analysis of Mean Achievement Scores of male and female students taught using Reciprocal Peer Tutoring Instructional strategy

\begin{tabular}{|l|l|l|l|l|l|l|}
\hline Source & $\begin{array}{l}\text { Type III Sum } \\
\text { of Squares }\end{array}$ & Df & Mean Square & F & Sig. & Decision \\
\hline Corrected Model & $90.156^{\text {a }}$ & 2 & 45.078 & .978 & .381 & Not Significant \\
\hline Intercept & 505.028 & 1 & 505.028 & 10.957 & .001 & \\
\hline Pretest & 79.348 & 1 & 79.348 & 1.721 & .194 & \\
\hline Gender & 9.820 & 1 & 9.820 & .213 & .646 & \\
\hline Error & 3457.023 & 75 & 46.094 & & & \\
\hline Total & 104060.000 & 78 & & & & \\
\hline Corrected Total & 3547.179 & 77 & & & & \\
\hline
\end{tabular}

The ANOVA analysis in table 4 shows f-value of 0.213 is not significant at 0.646 for the sex at 1 and 75 degree of freedom (df). This is because 0.646 is greater than 0.05 significant earlier set for hypothesis. Therefore, the $\mathrm{H}_{\mathrm{O} 2}$ is upheld indicating that there is no significant difference in Computer Studies academic achievement between male and female students taught using reciprocal peer tutoring instructional strategy.

\section{FINDINGS}

From the results of the data analyses, it was found that:
1. Students' taught Computer Studies using reciprocal peer tutoring instructional strategy recorded higher achievement than those taught using conventional method (Lecture method). There is a significant difference between the mean achievement scores of the experimental and control groups.

2. Female students recorded slightly higher achievement than their male counterparts in both the experimental and control groups. There is no significant difference in Computer Studies achievement between male and female students 
taught using reciprocal peer tutoring instructional strategy

\section{DISCUSSION}

The study examined Peer Tutoring Instructional Strategy and Senior Secondary School Computer Studies Students' Academic Achievement in Enugu State, Nigeria. The first finding revealed that there is significant difference in Computer Studies academic achievement between students who are taught using reciprocal peer tutoring instructional strategy and those taught using conventional method (lecture method) This implies that subjects in the experimental group who were exposed to reciprocal peer tutoring instructional strategy performed better than the subjects in the control group who were exposed to conventional (lecture) method. This finding concurs with Nwosu [25], and Sayyed and Mohammed-Rezza [26] which revealed that reciprocal peer tutoring strategy improves students' academic achievement. It can be deduced from the result reported above that peer tutoring transformed the classroom from a place for the dispensation of knowledge into a place where knowledge is approached from multiple and missing perspectives, thereby allowing students to learn from one another. Invariably, peer tutoring depends on the process of mutual help between classmates, allowing the transfer of control to the students in the classroom. Peer tutoring allowed the teacher to accommodate a classroom of diverse students. The teacher selected the content and acted as a moderator for each lesson. The teacher got involved when the tutors had difficulty explaining a particular concept or had issues understanding the language the tutee was using.

Furthermore, the study upheld the hypothesis that states there is no significant difference in Computer Studies academic achievement between male and female students taught using reciprocal peer tutoring instructional strategy. Reciprocal peer tutoring had no gender bias with respect to improving students' academic achievement; that is, peer tutoring did not favour male over female or vice-versa. This is in line with similar studies by Oviawe [18], Uwameiye and Aduwa-Ogiegbean [27], and Ukadike [28] who reported no significant difference in the academic achievement in prevocational subjects and sciences of both male and female students exposed to peer tutoring. However, this finding is at variance with Madu [29] who reported a significant difference in the academic performance of male and female students when exposed to a peer tutoring instructional strategy.

\section{CONCLUSION}

The study revealed that the use of reciprocal peer tutoring approach in teaching have well noted facilitative effects on students' academic achievement in Computer Studies. The result of the students taught Computer Studies using reciprocal peer tutoring approach have a significantly greater achievement than those students who were taught using conventional (lecture) method. Secondly, the study also revealed that the female students scored slightly higher than their male counterparts who were taught Computer Studies in Enugu East Local Government Area using reciprocal peer tutoring method. It therefore revealed that gender has no significant effects on students' academic achievement in Computer Studies, thus male and female students differ slightly in their academic achievement in Computer Studies.

\section{RECOMMENDATIONS}

Based on the findings, of the study the following recommendations are proffered:

1. There should be training and retraining of teachers through seminar and workshops organized by schools, non-government organization and ministries of education to aid the teacher's acquire and adopt students centered approach in teaching to improve the student's academic achievement in Computer Studies .

2. Management of institutions should organize and sponsor seminars, conference and workshops in every secondary school during the long vacation to educate the teacher's on the new findings to better the students' academic achievement in their areas.

3. Government at all level should in providing special grant to enable teachers undergo professional training courses in their area of specialization.

4. The various teacher education programmes in Colleges of education and Universities should incorporate peer tutoring instructional strategy into their various teacher education programs so as to prepare teachers on how to conduct instructions in Computer Studies using peer tutoring.

\section{REFERENCES}

1. Federal Republic of Nigeria. National Policy on Education. Abuja: NERDC; 2014.

2. Ebenebe RC. Qualitative teaching and learning environment. A lead paper presented at the 28th Nigerian Academy of Education Annual congress held at Nnamdi Azikiwe University, Awka, Anambra State;2013.

3. Ogbaekirigwe AC. Analysis of constraints to effective supervision of business studies in junior secondary schools in Ebonyi State. Journal of Business and Vocational Education, .2010; 1(1): 121-129.

4. Cantrell D. Using a variety of teaching methods and strategies. Recovered from online. Goggle search.2004.

5. Obeka SS. EPODEWALD and Power Simulation Games of Geographical and Environmental Education. Zaria Ahmadu Bello University Press Ltd. Kaduna State Nigeria.2009.

6. Bichi SS. Effects of Problem Solving Strategy and Enriched Curriculum on Students Achievement in Evolution Concepts among Secondary School Students. Unpublished Ph.D Thesis. Faculty of 
Education, Ahmadu Bello University, Zaria; 2002.

7. Usman IA. Using a Selected method of teaching in Enhancing Slow Learners Academic achievement Among Junior Secondary School Integrated Science Students.2008.

8. Awotua-Efebo EB. Effective Teaching: Principles and Practice. Paragraphics, Port Harcourt.2001.

9. Sanders D. "Peer tutoring in higher education", Studies in Higher Education, 2001; 17(2, pp. 211218.

10. Freedman MP. The Influence of Laboratory Instruction on Science Achievement and Attitude Towards Science Across Gender Differences. Journal of Women Minority in Science and English. 2002; 8(2) 50.

11. Omoniyi OA. The Effect of Constructivist Based Teaching Strategy on Gender-Related Differences on Students' Misconceptions in Chemistry. Ministry of Education, Akure, Nigeria. 2006.

12. Moreneo C and Duran D. Frameworks: Cooperative and collaborative methods. Spain: Edebe; 2002.

13. Rohrbeck CA, Ginsburg block A, Fontuzzo TR and Miller SR. Peer-assisted learning interventions with elementary school students: a meta-analytic review. Journal of Educational Psychology. 2003; 95(2): 240-257.

14. Paul G. Lisa F, Vanesa T. Effects of peer tutoring attitude and personality on academic performance of first year introductory programming students. $36^{\text {th }}$ Frontiers in Education; 2006.

15. Fuchs D, Fuchs LS, Mathes PG and Martinez EA. Preliminary evidence on the social standing of students with learning disabilities in PALS and noPALS classrooms. Learning Disabilities Research \& Practice. 2002; 17(4), 205-215.

16. Whitman NA. Peer teaching: To teach is to learn twice. Washington, DC: ERIC Clearinghouse on Higher Education; 2012.

17. Annis LF. The processes and effects of peer tutoring. Human Learning. 2013; 10(1), 39-47.

18. Oviawe JI. Effect of peer tutoring assisted instruction on students' academic achievement in introductory technology. FCT Education Secretariat Journal of Curriculum studies and Instruction. 2008; 1(1), 77-84

19. Okeke EAE. Making science education accessible to all. 23rd Inaugural lecture of the University of Nigeria, Nsukka. 2007.

20. Oyenuga A. Effect of model on technical college student's interest, academic achievement in auto mechanic. Unpublished Ph. D Thesis, University of
Nigeria, Nsukka; 2010.

21. Jimoh JA. Effects of two and three dimensional techniques of AutoCAD on spatial ability, interest and achievement of national diploma students in engineering graphics. Unpublished Ph.D Thesis, University of Nigeria, Nsukka; 2010.

22. Nzewi UM. It's all in the brain of gender and achievement in Science and Technology Education. 51 st Inaugural Lecture of the University of Nigeria, Nsukka; 2010.

23. Ogundola IP and Fakorede SO. Effect of scaffolding instructional technique on the achievement of auto mechanics students in senior secondary schools in Ekiti State, Nigeria. Educational Focus. 2009; 2(1).

24. Owodunni AS and Ogundola IP. Gender differences in the achievement and retention of Nigeria students exposed to concept in electronic works trade through reflective inquiry instructional technique. British Journal of Education, Society \& Behavioural Science. 2013; 3(4):589-599. Available:www.sciencedomain.org

25. Nwosu KC. Effect of reciprocal peer tutoring on test anxiety and academic achievement of students. 2014; Retrieve on 20 ${ }^{\text {th }}$ April, 2020 from https://nauligitdlibrary, wordpress.com

26. Seyyed AO and Mohammed-Rezza S. Effect of reciprocal teaching strategy on EFL learners' reading proficiency. Journal of Language Teaching and Research. 2011; 2(6), 1238-1243

27. Uwameiye R and Aduwa-Ogiegbaen SEO. Effect of reciprocal peer tutoring on the academic achievement of students in introductory technology. International Journal of Instructional Technology and Distance Learning. 2006; 3(6), 41-47.

28. Ukadike OJ. Effects of instructional methods, prior knowledge and sex on social studies achievement (Unpublished Master's Thesis) Department of Educational Psychology and Curriculum Studies, University of Benin, Benin City, Nigeria; 2005.

29. Madu BC. Effects of a constructivist-based instructional model and students' conceptual change and retention in physics (Unpublished doctoral dissertation). Sub-Department of Science Education, University of Nigeria, Nsukka, Nigeria; 2003.

30. Owodunni AS. Gender inequality in technical and vocational education: A challenge to female education in Nigeria. ASO Journal of Educational Studies. 2009;1(2):1-10. 